\title{
GLAUBER ROCHA ENSAÍSTA
}

\author{
Arlindo Rebechi Junior
}

arlindorebechi@usp.br

Quando alguém se coloca a refletir sobre a vida intelectual de Glauber Rocha, o mais comum é pensar na figura do cineasta. E não é por menos. Por detrás dela vislumbra-se a força das suas imagens orquestradas por uma câmera: do sertão messiânico de Deus e o Diabo na Terra do Sol (1964); da tensão entre o mundo individualizado, internalizado do poeta, jornalista e militante Paulo Martins, e o mundo do seu confronto, cuja realidade conformista reina e domina o Estado entorpecido de Eldorado em Terra em Transe (1967); do "matador de cangaceiros" Antonio das Mortes, de O Dragão da Maldade contra o Santo Guerreiro (1969); da África de O leão de sete cabeças (Der Leone Have Sept Cabeças, 1970). E o que dizer do Di Cavalcanti construído em contexto fúnebre por Glauber, no Di (1977), e da figura de Cristo em A Idade da Terra (1980), além de tantos outros filmes e tantos outros personagens compostos pelo cineasta aqui e no exterior? A lista não para nestes exemplos e pode ser ainda espichada em um sem número de cenas e sequências captadas pela câmera nervosa que marcou a mise-en-scène de Glauber.

Dito isso, não deixando de se compreender a relevância do cinema de Glauber e da crítica que ao redor dele gravita, convém salientar outro foco de possibilidades: seus escritos. O problema não é de hoje; já está disposto lá atrás.

Em 1963, em função das polêmicas geradas pela publicação do livro Revisão crítica do cinema brasileiro, de Glauber Rocha, o periódico Última Hora e a Fundação Cinemateca Brasileira promoveram um debate com 
alguns figurões da crítica e do cinema brasileiros de então. Interessa saber a opinião de um deles. Na ocasião, Paulo Emílio, então conservador da Cinemateca, deu uma declaração de penetrante alcance sobre o livro em debate e, mesmo anos depois, são palavras que ainda têm o mérito de nos expor as razões que justificam os estudos dos escritos de Glauber. Diz ele:

"O livro nos interessa porque nos interessamos pela personalidade dele [Glauber Rocha], sentimos que há uma personalidade criadora que tem importância no cinema brasileiro. O tal "autor" é o próprio G.R., porque digere tudo, faz o que bem entende das coisas, não toma conhecimento das coisas como elas são. De acordo com a personalidade afirmativa que ele tem, interpreta tudo à luz dos problemas que o estão preocupando no momento. Isso é importante para a gente sentir não só os limites, mas também o interesse do livro, de que forma pode ser um livro interessante e curioso, de que ângulo muito particular pode ser levado a sério". (GOMES, 2003. p. 207).

Décadas depois, Ivana Bentes, organizadora da importante obra da correspondência de Glauber Rocha, vai também apontar a relevância dos seus escritos. Por estes, visualizamos uma nova forma de abordagem de sua obra e, consequentemente, a lacuna que existe em sua fortuna crítica. Afirma, assim, Ivana Bentes:

\begin{abstract}
"Glauber não foi apenas um correspondente compulsivo, foi um escritor obsessivo, que passou mais tempo sobre a máquina de escrever que atrás de uma câmera. Ao nos defrontarmos com seus escritos, mais de quinhentas cartas, roteiros, poemas, ensaios, entrevistas, textos conceituais e confessionais, surge a pergunta decisiva: onde termina sua "obra" e até que ponto essa produção textual, de uma exuberância barroca, se integra a toda uma vida marcada pelo cinema?

Diante desse sem-fim de papéis guardados ao longo de quase trinta anos, carregados em malas, pastas e baús pelos quatro cantos, numa errância nômade, outra questão se impõe: já é hora de tirar Glauber do "gueto" do cinema e inseri-lo na história da cultura e do pensamento contemporâneos, da qual o seu cinema faz parte”. (BENTES, 1997, p. 9).
\end{abstract}

Entre uma declaração e outra, passaram-se mais de três décadas. Em 1963, Paulo Emílio estava ainda diante de um jovem cineasta, autor de apenas dois filmes - Barravento e Deus e o Diabo na terra do sol. Já Ivana Bentes, em final dos anos 1990, estava diante do já mitificado autor de Terra em transe e $A$ idade da terra. Mesmo que sejam estudiosos de diferentes épocas, um eixo, porém, parece comum às duas declarações: ambos entendem que os escritos de Glauber devam ser levados a sério para se descortinar a figura do intelectual de cultura brasileiro, que também é cineasta. 
Não concentrar em seus discursos produzidos por seus filmes e assumir os escritos de ensaio de Glauber Rocha como possibilidade de um detido estudo traz algumas implicações que precisam ser mais bem esmiuçadas aqui.

A primeira das implicações refere-se à própria postura que o pesquisador deverá ter diante do seu objeto. Escrevo algumas palavras sobre isso.

Todo campo de investigação delimita de modo particular seu objeto. Com Glauber e seus ensaios não poderiam ser diferente. No conjunto formado por seus textos está contemplada uma multiplicidade de interações: dos escritos com Glauber, dos escritos com a recepção social destes, do escritor com outros intelectuais contemporâneos, com os grupos artísticos e com as instituições que ele se relaciona.

Na base de toda essa convivência, nem sem sempre pacífica, Glauber engrossa o coro daqueles que participam de uma vida literária e cultural de um tempo. Constituída de uma incessante aproximação e separação das ações e reações entre seus indivíduos, tal vida literária - em larga escala, tal como a própria sociedade - é um fenômeno cheio de dinamismos, constituído, sobretudo, pelas formas que assumem as motivações e os impulsos destes seus indivíduos. E com Glauber não foi diferente.

Ao investigar Glauber Rocha e seus ensaios, neste campo de interação social, minha preocupação se volta para a forma pouco estável que é a própria dinâmica social em que está inserido o fenômeno literário. Nosso autor vivendo uma vida literária de um tempo assume para si uma forma literária que se torna, ao estudioso, um corpo observável. Por mais temerária que possa parecer, minha tarefa ante Glauber Rocha está enviesada justamente aí: convém observar tal vida social, incluindo nosso autor, interpretá-la e dar certa vida ao que se passou pelas mãos do escritor. Não uma vida completa, cheia de inteiras "verdades", mas uma vida constituída da observação e análise daquele que olha em retrospecto e assume, conscientemente, as contradições, as idas e vindas, o consenso e o conflito, típicos daquela vida literária de um tempo. Como crítico de Glauber, terei a favor aquilo que resistiu ao tempo, o que se cristalizou de uma prática escrita do escritor, aquilo que restou do seu fazer intelectual. Refiro-me aos seus ensaios.

Glauber foi um intelectual de muita mobilidade em suas ações intelectuais e culturais. Esteve ambientado não só no Brasil, como participou de um amplo debate cultural no hemisfério norte. De uma ampla capacidade de adaptação às diversas experiências e circunstâncias que ele enfrentava, seus escritos refletem os passos dessas transformações. 
Diante disso, é o caso de se perguntar: qual espaço de divulgação Glauber privilegiou para a prática escrita do ensaio?

O intelectual baiano foi, em todos os sentidos, um colaborador contumaz de jornais e revistas na imprensa brasileira e internacional. Quando não estava escrevendo um artigo, estava ele opinando em uma entrevista. Seus livros de não-ficção publicados em vida - Revisão crítica do cinema brasileiro e Revolução do cinema novo - são em parte a reconstituição desses seus lances e percursos de imprensa.

Pelas páginas dos textos seriados, ele mostrou-se um escritor ousado. Não porque havia desafiado - como de fato fez - críticos e artistas contemporâneos. Mas porque privilegiou o espaço desses veículos, fossem alternativos ou de grande circulação, para a manifestação de uma forma de texto: o ensaio de suas ideias e interpretações sobre nossa realidade artística e política. Não à toa, ele criou um movimento de duplo sentido. Sua experiência ensaística tornara-se dependente da sua produção seriada de textos, bem como esta também se ligava ao balão de ensaio vindo das transformações no calor das disputas intelectuais e de suas ideias fervilhantes.

Ao mesmo tempo em que Glauber tinha o desafio de escrever no jornal, num espaço convencionalmente considerado para ser consumido às pressas pelo leitor diário, ele mostrou-se com habilidade suficiente para considerar este espaço bastante propício para o ensaio de suas ideias, mesmo que assim fossem no calor dos acontecimentos ou no dia a dia. Tratado como documento das práticas de seu escritor, quase um diário do seu pensamento criador e intelectual, cada texto, no que trazia de ideias originais e problemas, ligava-se a outro e assim sucessivamente até se formular um mosaico cheio de interpretações - verdadeira mostra da sua experiência de ensaísta.

Convém notar mais de perto o exemplo de uma de seus principais exercícios de ensaio. Trata-se de focalizar suas colaborações na Folha de S. Paulo, no final da década de 1970.

\section{ABERTURA POLYTYKA, ABERTURA EZTÉTYKA}

Ao leitor de hoje, talvez cause certa estranheza um primeiro contato com os textos da coluna de Glauber Rocha, publicados, em geral, na página dois do caderno Ilustrada, na Folha de S. Paulo, no ano de 1978. A causa da estranheza não se limita aos aspectos de conteúdo abordado, embora estes fossem muito polêmicos e provocativos. Ao lançar-se no 
papel, a língua afiada de Glauber segue o mesmo ritmo febril de seus vulcânicos pensamentos. Convivem, uma junto à outra, duas ações linguísticas, possíveis causas iniciais do referido estranhamento: uma radical liberdade sintática ritmada pela oralidade exacerbada, própria, esta, de sua intemperança retórica, e o uso de palavras com uma grafia distintiva e original, longe, em muito, da ortografia clássica do convencionalismo dos dicionários. Miséria transforma-se em "myzerya"; Brasil em "Brazyl”; político em "polytyko", e assim por diante. Lado a lado, caminham-se o seu balanço temático e o seu balanço formal.

Tal evidência solicita um questionamento: qual a razão da adoção desta nova forma ortográfica? O que ela significa para o intelectual em sua condição recente naquele momento de ex-exilado? O que isso sugere dentro de seu balanço de fatos e ideias do momento?

Em 1956, o pensador alemão Theodor Adorno publicou o texto "Sinais de pontuação", mais tarde reunido em seu célebre livro Notas de literatura I (1958). Como de praxe, o lance interpretativo de Adorno, carregado como sempre de um "estilo atonal" e de um ensaísmo fragmentário e ao mesmo tempo totalizador das ideias e conceitos, partiu para o inusitado. Sua especulação filosófica procurou desvendar, dentro das condições inerentes à própria escrita, o "status fisiognomônico" (ADORNO, 2003, p. 141) dos sinais de pontuação. É desse modo que o ensaísta alemão remeteu sua análise aos aspectos constituintes de linguagem presentes nos sinais gráficos de pontuação e ao caráter vivo e histórico destes. Adorno vinha demonstrar a relação conflitante entre os escritores e a forma e o uso dos sinais de pontuação. A escolha entre um travessão, um parêntese ou os pontos de reticências poderia, no fundo, revelar as opções da visão social e de mundo de um escritor. Ainda mais. Adorno demonstrava que se estes, os sinais, por certo eram inseparáveis da função sintática de um texto, nesta mesma função sintática eles, em contrapartida, não poderiam se esgotar.

Rica e envolvente, a matéria levantada pelo pensador alemão serve de estímulo para que se reflitam as entranhas tipográficas presentes no texto glauberiano, no sentido de apontar seu valor mais duradouro e suas implicações com a visada histórica ali presente. Proliferam-se nos textos articulados por Glauber para a Folha não só o uso dos travessões, dos pontos de exclamação, de interrogação, pontos-e-vírgulas, entre outros sinais, mas também o uso das demarcações tipográficas representadas nas grafias de palavras em maiúsculas (padrão de caixa-alta no meio editorial) e nas substituições em muitas palavras do "s" por "z", do "i" por "y" e do "c" por "k". 
Glauber imprime aos seus textos um estilo singular na montagem das ideias. Parte para um estilo de exposição que privilegia a disposição de ideias na forma de fragmentos, como se fossem pequenos e explosivos textos. Encadeados um atrás do outro, estes minúsculos textos, formam um conjunto que ganha tanto pela independência de ideias como pela capacidade de se misturarem num fio condutor único e presente no texto. Fica a demonstração nestes casos que sua busca por este estilo atesta uma hipótese central em seus trabalhos: a aliança e a conjugação em sua prática escrita com as tensões e os contrastes da experiência vivida, para, assim, extrair sua matéria mais vulcânica e mais polêmica da realidade.

Antes de mais nada, é preciso notar que tais elementos gráficos (sinais de pontuação e ortografia original) são responsáveis em parte significativa na composição deste estilo. Através deles se formula a cadência do fraseado e do fluxo constante de imagens trazidas pelo ensaísta baiano. Através deles se impelem o silêncio ou grito que nas páginas dos jornais transformam-se mais do que nunca uma voz de opinião pública. Através deles se atenuam elementos não proveitosos para sua argumentação ou evidencia aqueles que ele desejava apoiar ou mesmo através deles protestar. O que, convenhamos, já não é pouca coisa.

No que se refere ao seu estilo de montagem, o paralelo mais evidente na literatura brasileira é a poesia de Oswald de Andrade. Haroldo de Campos, em crítica ao livro Pau-brasil (1925), foi muito feliz quando nota o novo conceito de livro que aquela poesia propunha: "Seus poemas dificilmente se prestam a uma seleção sob o critério da peça antológica. Funcionam como poemas em série. Como partes menores de um bloco maior: o livro." (2000, p. 35).

Ultrapassando seu aspecto de organização sintática, portanto sua função gramatical, introjeta-se, nesta pontuação e nesta forma particular de grafia das palavras, a história compartilhada pelo e do seu próprio autor. Explico melhor. Não é incomum nos textos de Glauber que um travessão ganhe o estatuto de um traço de pensamento, que ultrapassa em longe o papel de pausa que introduz uma inserção parentética. Por uma forma autoritária da retórica glauberiana, uma exclamação pode tornar-se um elemento que estabelece a ligação a uma ordem externa, num gesto, também autoritário, em que o ensaísta consegue dar ênfase àquilo que só o encadeamento lógico de ideias poderia formalizar, embora sem a devida força no ato da escrita. É neste caso, por exemplo, guardadas aproximações e proporções devidas de época, que Glauber se aproximaria à retórica vibrante de um Euclides da Cunha. Refiro-me aos 
textos de jornal do autor d'Os Sertões, quando na cobertura jornalística de Canudos, ele, volta e meia, bradava suas palavras num retumbante "Viva a República!". Sem ficar atrás, Glauber anunciaria, quase um século depois, o seu "Que VIVA BRAZYL!" (ROCHA, 17 jun. 1978, p. 30). As reticências são outro exemplo de forma e uso da pontuação aplicados ao estilo. Elas estão presentes em seus vários textos de colunista. Mais do que consagrar uma atmosfera fictícia para demarcar o fraseado sob um sentido inacabado, as reticências são a marca gráfica que sugere chaveamento no fluxo de ideias e fragmentos trazidos à tona por aquela escrita febril e disparada de Glauber.

No fundo, o uso de todos esses sinais gráficos, aliando-os à montagem das ideias em fragmentos, reforça uma exigência do autor Glauber. Trata-se, até o limite do possível, da sua rejeição ao convencionalismo das regras gramaticais. Embora não só isso. Sua rejeição também está diretamente ligada à parcela de discursos produzidos no campo político e artístico. Volto a salientar que Glauber vai até o limite do possível, pois, como já havia notado Adorno em relação à elaboração e utilização da gramática no jogo literário, se ele, o escritor, "não pode confiar nas regras frequentemente rígidas e grosseiras” (ADORNO, 2003, p. 148), ele também não pode ignorá-las por completo, sob o risco de cair no ostracismo e ser vítima de si mesmo, da própria excentricidade. E desta dinâmica particular Glauber não estava blindado.

\section{INTELECTUAIS À BRASILEIRA POR GLAUBER OU ALGUMA COISA QUE VEIO DE IRACEMA ATÉ MACUNAÍMA}

Sergio Miceli, em seu já clássico estudo Intelectuais e classe dirigente no Brasil (1979), oferece uma síntese privilegiada do processo cultural entre as décadas de 1920 e 1940. Seu foco de análise recai sobre os intelectuais e suas relações, bem como suas estratégias lançadas, para alcançarem destaque e posições em carreiras intelectuais nos setores público e privado, em sua expansão de postos de trabalho. As contribuições do estudo de Miceli são muitas, mas uma delas, a meu ver, se destaca por trazer argumentos bastante válidos para o cerne da discussão acerca do grupo de intelectuais cooptados pelo Estado.

Trouxe o estudo de Miceli como referência para dizer sobre as tarefas políticas que engajaram gerações de intelectuais desde os tempos do Império. De um modo ou de outro, intelectuais ligados ao Estado sempre estiveram envolvidos nas demandas políticas solicitadas por seus 
representantes. Antes do regime Vargas, tais intelectuais dependiam quase que exclusivamente de chefes políticos oligárquicos. Depois de instituído o regime, dependiam muito mais de uma elite burocrática cada vez mais forte em termos políticos (Cf. MICELI, 2001, p. 198). Enfim, a partir do estudo pioneiro de Miceli, o que se começa a notar com maior efeito é uma ligação bastante íntima entre classe intelectual e demandas políticas existentes na vida social.

Para o momento, cabe notar que a visão de Glauber - refiro-me aos seus textos de depois do exílio - privilegia o intelectual engajado com uma agenda política. Mas não qualquer agenda política. Nem qualquer perfil de intelectual. É o caso, sem dúvida, de se avaliar que tipo de intelectual estaria ele valorizando. Antes de adentrar nos comentários dos textos produzidos para sua coluna na Folha, abro espaço para debater um perfil intelectual por ele valorizado e um perfil intelectual por ele rejeitado, dando uma dimensão inicial do problema.

Trata-se de uma polêmica reavivada no ano de 1976: AlencarMachado.

Glauber chega ao Brasil em 23 de junho de 1976, numa quartafeira. Já no sábado, dia 26, o Jornal do Brasil publica uma página de sua entrevista, em que mais uma vez o cineasta baiano faz um de seus balanços. O primeiro em sua volta. Em pauta: o saldo final do exílio, as novas perspectivas para o cinema brasileiro de então e os valores presentes na vida intelectual brasileira. Perguntado, ao final, se existiria no momento uma saída possível para a crise vivida por nossa arte, Glauber dá a seguinte resposta: "O Brasil produz uma arte forte, viva, violenta, popular, colorida, erótica, barroca, tropical, generosa, e cuja característica principal é a sua indisciplina, seu antiacademicismo. Com exceção de Machado de Assis, que é o sistema da cultura reprimida, e por isso feito para a censura. Mas Guimarães Rosa, e Drummond não são, nem Oscar Niemeyer projetando Brasília. Eles estão além disso. Daí decorre o drama de todos os Estados que querem produzir uma arte à sua imagem, quando a arte é a anti-imagem, porque é outra imagem escondida. $\mathrm{O}$ charco burocrático não cria. A arte brasileira só pode existir a partir da sua indisciplina" (ROCHA, 26 jun. 1976, p. 1).

Dias depois, um novo depoimento no jornal alternativo Movimento, de São Paulo. E Glauber, nesta entrevista, desdobra a ideia, antes mencionada no Jornal do Brasil, sobre Machado de Assis, acrescentando outros elementos à polêmica: "E a estética só é grande quando é livre. E a principal característica da arte brasileira é sua indisciplina. Exemplo: Machado de Assis é um escritor que escreve para ser censurado, porque 
é um acadêmico. Então é o escritor por excelência responsável pela mediocridade; é um modelo que impõe uma mediocridade literária que imita um padrão. O censor entende Machado de Assis. O Guimarães Rosa é um escritor para não ser censurado, porque o censor está diante de uma língua nova. Então, um artista que quer ser censurado apresenta um estilo suscetível de ser censurado [...] O responsável pela censura é Machado de Assis, que determina um tabu linguístico, tremendamente moralista e conservador" (ROCHA, 19 jul. 1976, p. 19).

Duras palavras ao escritor de Dom Casmurro. Tão duras que há de se entrever que por detrás delas estejam demonstrações e rejeições de compatibilidades do que Glauber considera um autêntico intelectual nacional. As declarações dadas ainda sob o impacto de sua chegada ao Brasil apenas registram a ponta do iceberg.

Numa das reações que suas palavras suscitaram destaca-se a polêmica dele com o então editor de cultura do semanário Movimento, Flávio Aguiar. Em 9 de agosto de 1976, neste mesmo semanário, o crítico literário porto-alegrense alfineta Glauber com o artigo de longo título: "E geme o sino em lúgubres responsos Pobre Glauber! Pobre Glauber! (ou: 'Nem Lênin, nem Stalin, nem Marx, nem mesmo Machado de Assis'. E muito menos Glauber Rocha)". Tal título, tomado do último verso de Alphonsus de Guimaraens, do poema "A catedral”, em que o próprio poeta a si evocava a angústia do dia que se passava, sob os badalos do sino da igreja: "Pobre Alphonsus! Pobre Alphonsus!", registra uma intenção de Flávio que se confirma com o desenrolar do seu artigo. Flávio Aguiar, neste artigo, diz não querer desentranhar o Glauber de ontem, personagem central dos nossos avanços cinematográficos, para desvelar esse Glauber de então, "disposto a ser uma espécie de enfant terrible de nosso vazio cultural” (AGUIAR, 9 ago. 1976, p. 15). Sua estratégia foi outra. Ao invés de utilizar a mesma moeda de troca de Glauber, Flávio apenas propõe que esperamos. Sejamos pacientes. No aguardo para que, segundo ele, "esse Glauber aprenda, como aprendemos, com o outro" (AGUIAR, 9 ago. 1976, p. 15). Que aprendesse, por exemplo, com seu próprio personagem Antonio das Mortes, que depois de dois filmes, aprendeu a enxergar alguns palmos além do próprio nariz. Flávio ainda justifica que a atitude de Glauber só vinha provar algo. Diz ele: "o cinema brasileiro precisa de cada vez menos de enfants terribles, que servem de diversão muitas vezes a quem olha a arte como diletantismo, e muito mais de gente adulta, com o discernimento crítico, que, com criatividade, espírito combativo, seja no drama ou na sátira, saiba distinguir o sul do norte, o leste do oeste e o Machado da tesoura" (AGUIAR, 9 ago. 1976, p. 15). 
A réplica, até certo ponto exagerada de Glauber, vem pelas páginas do Pasquim. Acusa o jornal Movimento de fazer sensacionalismo com seu nome: "vamos vender a cabeça da fera pra vender mais jornal" (ROCHA, 13-19 ago. 1976, p. 14). Mas é na questão Machado de Assis que Glauber nota uma espécie de censura por parte do semanário. Diz ele, em alto e bom som:

\begin{abstract}
“Se o pessoal do 'Movimento' estivesse no poder Glauber Rocha cineasta revolucionário do Terceiro Mundo seria fuzilado porque esculhambou Machado de Assis. Porque veio um crítico chamado Flávio de Aguiar, inocente útil a serviço de Jean Claude Bernardet, anunciar em dobres fúnebres nas páginas de 'Movimento' minha morte [...] Vivemos num país democrático onde a censura do governo permite que eu publique materialismo dialético onde o 'Movimento' em nome da Revolução brasileira pede minha cabeça porque eu esculhambei com Machado de Assis. De quem é a censura?" (ROCHA, 13-19 ago. 1976, p. 14).
\end{abstract}

Se o próprio Pasquim abriu seu espaço para a tréplica de Flávio Aguiar (10-16 set. 1976, p. 19), que ocupou o espaço para se defender das acusações de Glauber quanto à censura de Movimento em relação a sua entrevista, foi nas páginas deste semanário carioca que Glauber continuou suas reações contra Machado. Passamos mais perto por suas novas reações. Coincidência ou não, ao que tudo indica o cineasta baiano fora ainda mais motivado por uma discussão vinda diretamente de Brasília, das tribunas do Congresso Nacional. Em primeiro de setembro daquele ano, o senador Luiz Viana, da Arena da Bahia, também acadêmico da ABL, fez um longo discurso em que expressa uma antiga celeuma: deveria Machado de Assis ser o patrono das nossas letras ou o papel seria de José de Alencar? Em andamento naquela Casa e já aprovado pela Câmara dos Deputados, o projeto de autoria do deputado Alberto Lavinas declaravase em favor de Machado. Diferente, Luiz Viana se colocava a favor de José Alencar, segundo ele, o "inconteste criador da literatura brasileira" (VIANA, 2 set. 1976, p. 5336).

O discurso de Luiz Viana, cuja repercussão também gerou matéria no Jornal do Brasil (2 set. 1976), cerca o problema sem estabelecer um confronto entre os dois escritores. Tratava-se, como frisou, de atribuir a um deles o lugar que lhe era de direito. Um lugar dedicado a José de Alencar. Um lugar que "lhe competia na vida, na história e na formação das nossas Letras” (VIANA, 2 set. 1976, p. 5337). Para o senador, entre os motivos da autêntica brasilidade adquirida por José de Alencar estaria seu estilo, de uma língua que ele mesmo criou pelas singularidades sintáticas e vocabulares do falar brasileiro, de um pioneirismo, enfim, que 
o libertava dos laços de dependência com o mundo lusitano. Nada, desse modo, parecia mais justo para o político que, mesmo com a admiração incontestável por Machado de Assis, pudesse valer seu voto parlamentar e proclamar José de Alencar como o verdadeiro patrono das nossas letras.

Discurso feito pelo senador na quarta-feira, dia 1 , repercutido no dia 2, e Glauber já de opinião formada no dia 6 de setembro. Ocasião que escreve e publica o artigo “'O Guarany' e 'Dom Casmurro' ou a competição entre Iracema e Capitu pelo título de Misse Brazyl” para o Jornal do Brasil. Por se deter mais na polêmica, tal texto é chave para se detectar evidências mais substanciais da posição assumida pelo cineasta, deixando clara sua opção pelo tipo intelectual de José de Alencar e, ao mesmo tempo, negando o modelo intelectual de Machado de Assis. Resta saber as razões disso.

$\mathrm{O}$ artigo de Glauber começa pela digressão a uma conversa que ele havia tido, na França, com o crítico Roberto Schwarz, mais Leandro Konder e José Guilherme Merquior. Da conversa, o autor de Terra em transe conclui que há uma indisposição da crítica em relação ao nosso romantismo. Deixando transparecer que tal crítica está muito mais propensa a fundar o nosso verdadeiro romance por Machado de Assis, Glauber escreve, para em seguida contestar tal afirmação: "a tese geral de nossa crítica literária, não conheço discordantes, é a de que o nosso Romantismo não passa de reprodução da Europa. O índio alencariano ou gonçalvista não passa de um bom selvagem do Jango Jaca Russó" (ROCHA, 6 set. 1976, p. 10).

Os motivos de desagrado para com Machado de Assis, segundo Glauber, é sua carreira política pouco engajada, mesmo medíocre. Nesta perspectiva, toda a desenvoltura de Machado em galgar posições sociais em uma sociedade tão pouco permeável, quanto era o Rio de Janeiro daquele fin de siècle, não surtia nem um efeito social mais imediato na visão de Glauber. Tudo que lhe restava, assim, era o prestígio literário, marcado pela criação já em fase madura da Academia Brasileira de Letras e a constituição de uma "Legislação Estética, Apanágio da Mediocridade Parnasiana! Academia Símbolo da Última Flor de Lácio Oh Inculta e Bela!" (ROCHA, 6 set. 1976, p. 10). Glauber busca construir um Machado vulnerável ao mundo político, um autor que morre velho, cercado de amigos e protegido por um neutralismo das posições políticas: "Machado serviu ao Império e à República, a liberais e conservadores, nunca sujou as mãos nas senzalas, falou contra arte regionalista, negou a felicidade, viu o Brazyl com os olhos de Bentinho" (ROCHA, 6 set. 1976, p. 10).

De outro lado, o perfil intelectual construído por Glauber para José de Alencar ganha contornos épicos. Homem de posição política firme, 
apoiando o imperador quando fosse necessário, mas também entrando em desacordo em certos momentos, Alencar é visto como um intelectual capaz de ser aceito na corte pela excepcionalidade de seu talento tão apenas. Pois longe da elegância oratória de homens de corte, Alencar seria o "boêmio, playboy, dandy, político, malandro", carregando consigo, segundo suas palavras, as "taras nordestinas" (ROCHA, 6 set. 1976, p. 10).

Em contraponto ao que fora Machado, o cineasta inscreve Alencar como um desbravador do mercado interno das letras. Um escritor que conseguia equilibrar na balança a vida pública e política e o investimento de tempo e talento no mundo das artes. Não só isso. Para Glauber, era ainda um defensor do ideário de liberdade. Certamente, sem conhecer suas cartas dirigidas ao imperador a favor da escravidão (Cf. ALENCAR, 2008), o cineasta baiano formulava um perfil de cidadão justo e político exemplar para Alencar. Um político que proibia a venda de negros, sob pregão, em lugar público; um político que enfrentava quem pudesse ser dentro das cercanias do poder: "seus diálogos com Dom Pedro II são de homem pra homem, em nenhum repique Alencar se rebaixa diante do Grande Português" (ROCHA, 6 set. 1976, p. 10); um escritor que foi o que mais avançou diante da invasão de romances e dramas estrangeiros, no Rio de Janeiro do século XIX: "O Guarany fez o mesmo, ou mais, sucesso popular do que Os Miseráveis, de Victor Hugo, numa época em que o teatro era ruim, não tinha cinema e a novela era o folhetim" (ROCHA, 6 set. 1976, p. 10).

A tendência de Glauber ao analisar o perfil intelectual de José de Alencar é trazê-lo à lume a partir de sua visão contemporânea dos fatos. Neste redemoinho de perspectivas, é evidente que sua atualização delineia características no escritor de Iracema fora do seu tempo. Basta levantar os tipos alencarianos previstos por Glauber. O Alencar subversivo com o mundo político, o Alencar revolucionário e o Alencar feminista são apenas construções que têm muito da época vivida pelo cineasta e do próprio perfil que Glauber considerava mais adequado para um intelectual de nossa cultura. É desse modo que o perfil intelectual de Alencar torna-se o seu próprio espelho de vida intelectual. E Alencar e Machado espelhos da política nacional, sob sua concepção: “Alencar, um brasileiro típico candidato do MDB, é defendido por Luiz Viana, que não reconhece Machado patrono da velha bossa da Arena [...] Machado perde as eleições. Sua literatura é água encanada. A literatura de Alencar é o encontro do Negro com o Solimões" (ROCHA, 6 set. 1976, p. 10).

Glauber segue por um campo minado. Ao mesmo tempo em que separa Machado de Assis e José de Alencar em setores distintos de ação prática na vida intelectual dos seus respectivos tempos, ele também define 
uma opção sua desta mesma vida prática para o seu próprio tempo. Aliás, apresentá-los, tais perfis, como água e vinho, foi um caminho discutível de elaboração. Basta notar algumas repercussões de várias ordens em textos de época (AGUIAR, 20 set. 1976, p. 18). Porque, diga-se bem, a separação talvez não seja das mais fáceis de ser realizada, haja vista a permeabilidade de tempo histórico que ambos os escritores vivenciaram. A propósito, como a mão e a luva, a metáfora criada por Flávio Aguiar oferece uma interpretação mais sóbria para o caso: "Machado e Alencar são vinhos da mesma pipa, ainda que de safras diferentes" (AGUIAR, 20 set. 1976, p. 18). Mas há de se salientar, por outro lado, que Glauber também não buscava a sobriedade acadêmica na análise dos fatos. E sim a partidarização entre um e outro perfil. É desse modo que seria possível definir o seu intelectual de preferência por dois fatores: este não seria completo se apenas estivesse vinculado ao engajamento panfletário. Nem também cumpriria seu papel se apenas estivesse preso à própria prática de sua arte - sua arte por ela mesma. Alencar, portanto, é seu protótipo legítimo e nacional. Seu apoio para futuras observações.

Como se pode observar, a polêmica Machado-Alencar alimentada por Glauber fala muito além dos dois escritores. Sob seu próprio ângulo, frisa-se, ele polariza por dois perfis intelectuais: de um lado um suposto artista nacionalista e de outro o mito do artista omisso com os problemas nacionais e só preocupado com as sinecuras e os rendimentos que dela derivassem. Tanto Alencar como Machado, nesse horizonte de interpretações, tornam-se chave de interpretação para suas leituras de trajetórias. Glauber prosseguiria, em ano seguinte, em 1978, com os seus artigos de perfis intelectuais, dentro da coluna da Folha de S. Paulo.

Vejamos.

Como era de se esperar, as críticas de Glauber a Machado continuaram a aparecer na imprensa. Dessa vez, estampadas nas páginas da Folha. Em 3 de junho de 1978, no texto "Limite", o tema inicial de sua discussão, motivado pela oportunidade de Glauber ter assistido pela primeira vez o filme (homônimo ao título do artigo) de Mario Peixoto, é a decadência. Ocasião em que Glauber julga Limite (1931) como "produto de intelectual burguês decadente" (ROCHA, 3 jun. 1978, p. 30). Na discussão sobre o filme, Glauber encontra a brecha para a crítica a Machado de Assis. Não haveria, segundo ele, exemplo maior de um decadente em nossas artes e em nossa cultura do que o autor de Memórias póstumas. Neste sentido, ele faz supor que o gesto de decadência presente na vida e obra do escritor fluminense advinha da omissão para com o mundo, revolvendo-se, como se sabe, uma velha crítica, e já ultrapassada naquele fim de década, dirigida a Machado de Assis. Não é novidade que Glauber é passional. 
Sempre que pode ele dá uma dimensão pessoal às suas defesas. Veja-se uma clara demonstração de sua rejeição a Machado e a demarcação de uma de suas preferências: "o psicologismo satírico de Machado suprime a dramatyka luta de classes em nome dos minuetos ritualísticos do Segundo Ymperyu e por isso interrompi a leitura de 'Quincas Borba' e abri as delirantes páginas de 'Palmeiras Selvagens', romance de William Faulkner que o coloca o Heroy entre a Dor e o Nada" (ROCHA, 3 jun. 1978, p. 30).

Uma semana depois, em 10 de junho de 1978, as críticas continuam no artigo "Kranyo". Estas, muito mais contundentes que as anteriores. Para Glauber, em Machado de Assis, diferente de Alencar, há o compromisso com as elites. Diz ele:

"Enquanto as elites burguezas de D. Pedro II são contestadas pelas utopyas de José D’Alenkar, Gonçalves Diaz. Kastro Alves, Álvares de Azevedo, Kazimiro de Abreu - Machado de Assiz fetichyza os rituais decorrentes da kort.

Os signos de Machado são comprometidos com o liberalyzm escravocrata (...'uns crioulos de Mynas...' em Quincas Borba) - elegendo deliberadamente a dramaturgya da casa grande como centro de seu genyo" (ROCHA, 10 jun. 1978, p. 32).

Falar que Machado inclui a casa-grande como centro de sua literatura, no fundo, trazia dois efeitos para a caracterização do escritor fluminense. Tratava-se, nesta visão criada pelo colunista, de um autor apenas preocupado com o mundo de pompas e etiquetas da elite carioca, quando, na verdade, hoje sabemos que a entrelinha de Machado havia falado muito do que se supunha ele não ter falado. Além disso, para Glauber haveria uma tendência de Machado como escritor ao esquecimento da própria condição de mulato, não levando em conta, dessa forma, quaisquer ressonâncias vindas do mundo das senzalas. Daí Glauber, em mais de uma vez, chamá-lo, sob o vocabulário marxista, de um escritor alienado. Daí ele caracterizá-lo como um escritor mistificado, cuja obra, segundo o cineasta, "farfalham rendilhotas, velas do bolo, novela de Janet K. Clair, alienação mistificada pela crítica naturalista” (ROCHA, 10 jun. 1978, p. 32).

Sob certo ângulo do colunista, Machado de Assis é um fragmento de nossa literatura mais conservadora. Não só isso. Ele carregaria consigo também uma crítica favorável que estaria amparando uma visão falseada da nossa vida social e cultural. Razão que obrigava o cineasta, por certo, a confrontar a crítica de alguns machadianos com sua própria posição pouco conciliatória com Machado de Assis. É o caso de se ler com atenção o trecho a seguir, para que se possa dedilhar um breve comentário: 
“Com a conversão de Machado ao lyberalysmo ezkolaztyk d'Akademya Brasyleyra de Letraz, fundou-se a rezyztencya a revolução kultural: tese de que os romantykuz são repetecos do romantyzmo francês, Jorge Amado escreve mal, Gylberto Freyre fascista etc." (ROCHA, 10 jun. 1978, p. 32).

No centro do referido trecho, há um problema que Glauber levanta, cuja defesa sua vai em sentido contrário. Refiro-me à tese não aceita por ele de que os românticos incorporam o modelo de romance francês do século XIX. Seu horizonte de debate enxerga a crítica de Roberto Schwarz, então recém-lançada. Lembre-se que Ao vencedor as batatas é de 1977 e o texto de Glauber é de 1978. Época, portanto, em que as ideias de Schwarz ainda são recepcionadas no âmbito brasileiro.

Parece nítido que Glauber está contra a tese inscrita em uma das partes de Aovencedor as batatas, sobretudo aquela em que o crítico aponta as variadas respostas de Alencar na incorporação do molde europeu, que combinado à rica matéria local, produz uma série de efeitos, segundo ele, nem sempre bem-sucedidos sob a perspectiva literária. Há de se colocar que toda a construção de Glauber em defesa de Alencar poderia ruir-se, diante do método avassalador do crítico. É provável que entre as passagens mais indigestas para Glauber da obra de Schwarz esteja o seguinte trecho:

\footnotetext{
"Chega o romancista, que é parte ele próprio desse movimento faceiro da sociedade, e não lhe copia as novas feições, copiadas à Europa, como as copia segundo a maneira européia. Ora, esta segunda cópia disfarçada, mas não por completo, a natureza da primeira, o que para a literatura é um infelicidade, e lhe acentua a veia ornamental. Adotando forma e tom do romance realista, Alencar acata a sua apreciação tácita da vida das idéias. Eis o problema: trata como sérias as ideias que entre nós são diferentes; como se fossem de primeiro, ideologias de segundo grau. Soma em conseqüência do lado empolado e acrítico - a despeito do assunto escandaloso - desprovido da malícia sem a qual o tom moderno entre nós é inconsciência histórica. Ainda uma vez chegamos ao nó que Machado de Assis vai desatar" (SCHWARZ, 200o, p. 4647).
}

O trecho se torna indigesto a Glauber, pois o crítico ao mesmo tempo em que destaca o aspecto imitativo da obra alencarina também registra que entre nós apenas o tom moderno e malicioso de Machado teria conseguido superar de forma mais crítica tal inconsistência. Se Glauber institui Alencar como revolucionário das nossas letras - para ficarmos num termo moderno de uso constante nos escritos do autor de Terra em transe -, é evidente que aceitar o influxo externo na modulação da literatura deste escritor romântico tornava-se um disparate, um 
contrassenso para o cineasta. Ao contrário de Schwarz, a perspectiva de Glauber dispõe Alencar de uma malícia e de um trato original com a brasilidade a ponto de transformá-lo, como notado antes, no grande patrono das nossas letras e das nossas artes. Da mesma forma que Roberto Schwarz nota um defeito na "grandiloquência séria e central da obra alencarina" (2000, p. 50), cuja solução, segundo ele, viria com Machado de Assis e sua tonalidade grotesca, demonstrando que este sabia tirar proveito de um desajuste naturalmente cômico, em Glauber se nota o oposto em sua formulação. É a grandiloquência na abordagem, ajustada à cor local, que faz da obra alencarina alcançar sua dimensão épica e de transformação e, por consequência, fixação da forma do romance nacional. Sempre longe de uma neutralidade, isso só reforça que em Glauber falar de Machado é falar de Alencar e vice-versa. Falar da qualidade intelectual de um, no caso Alencar, é deixar à vista os defeitos de outro, os de Machado. Ainda sim, sem esquecer que existem casos, como veremos a seguir, em que falar de um perfil intelectual é remetêlo ao mito fundador, ao caso do perfil construído do patrono das nossas artes, conforme se disse.

Em23 de setembrode1978, eleescreveoartigo intitulado "Makunayma (1)", a primeira parte de um texto dedicado ao cineasta Joaquim Pedro de Andrade, autor do famoso filme Macunaíma, de 1969. A imprecisão com que Glauber lapida o perfil intelectual de Joaquim Pedro de Andrade tem sua razão de ser. Os fragmentos que desenham os contornos do seu personagem contemporâneo compõem um mosaico sob duas dimensões construtivas: a luta coletiva do autor de Os inconfidentes, cujo embate o ligava ao mundo do Cinema Novo, e o rigor e apego individual na ordem operacional da construção de sua obra multifacetada, ramificação, por assim dizer, poderosa deste mesmo Cinema Novo.

Espécie de um tipo alencariano, Quincas, como era chamado o cineasta de Macunaíma no ambiente carioca, é observado por Glauber como um intelectual que não se reserva à atuação apenas no campo cinematográfico. Suas filiações ultrapassam em larga escala o limite de uma arte apenas. A lista de Glauber é interminável. É discípulo de Plínio Sussekind Rocha, é ligado a Saulo Pereira (este, por sua vez, estivera ligado a Mario Peixoto do mitológico Limite), faz parte da "igreja de Octávio de Faria” (ROCHA, 23 set. 1978, p. 32), é da turma adepta das críticas de Vinicius de Moraes e de Alex Viany, e ainda por cima é filho de Rodrigo Melo Franco de Andrade, um dos fundadores do que hoje conhecemos por Instituto do Patrimônio Histórico e Artístico Nacional (IPHAN). Longe de servir para demonstrações da ligação do cineasta com a elite carioca, a lista de filiações numerada por Glauber presta-se para 
salientar o talento individual de formação heterogênea que justificava uma obra que ultrapassava a própria condição social do cineasta de $O$ padre e a moça. O que não causa nenhum espanto que Glauber escreva a respeito de Quincas, em certo momento do seu texto o seguinte: "o aristocrata ia ao povo", pois, afinal, "era povo. Rompia com a legenda de que se tratava de um esnobe que não bebia água em botequim pra não contrair moléstias populares nos copos" (ROCHA, 23 set. 1978, p. 32).

No segundo artigo dedicado a Joaquim Pedro de Andrade, o cineasta baiano dá prosseguimento às ideias tratadas no primeiro texto. Reiterase a figura de aristocrata que vai ao povo. Para isso, nada parece se ajustar melhor à tal imagem do que remeter, em plena sintonia, o autor, seu engajamento, e obra, uma das mais simbólicas representantes do Cinema Novo. Modelar, portanto, seria o que havia se construído e entrevisto pela representação de Macunaíma, um filme de considerável sucesso de público:

\footnotetext{
“'Macunaíma’ é o Klymax da experiência kyno-tropykalyzta de um cineasta que conquistou, pela comédia an-tro-po-fa-gi-ka, um público dominado, poluído, sob paternylização demagogykrymyna de críticos inspirados por Harry Stone, Jack Valenti, Pedro Tatlebaum e outros representantes dos interesses multinacionais que visam destruir as possibilidades de uma Indústria que 'conquiste' e não 'explore' o público, pratica dos pornô-historicistas que se identificam aqueles intelectuais desejantes de uma Arte Ruin ao alcance de todos...

Porque recusa o comercialismo criminal contra a cultura popular e ao controle estético-político dos Partidos ou Igrejas... O Kynema Novo, caminho ORYGYNAL, sofre violento boicote há 20 anos, dai ser redundante a atual campanha contra a Embrafilme" (ROCHA, 28 out. 1978, p. 40).
}

Glauber compõe um estilo individual e épico para Joaquim Pedro de Andrade. Como sua característica marcante, está o seu estilo anticomercial, no sentido daquele que se recusa a trocar a ideia por um preço. Um estilo que, como consequência, se encaixaria no estilo coletivo do Cinema Novo. Ao ponto de a mistificação de personagens dos filmes do cineasta carioca se juntar à mistificação do próprio autor.

O texto de Glauber cria um jogo para Joaquim: se seus heróis personagens passam por protótipos da sociedade brasileira, desde intelectuais de renome, como, por exemplo, Manuel Bandeira e Gilberto Freyre dos primeiros filmes de curta-metragem, passando pela lenda mítica de Macunaíma, e ainda interpreta uma figura popular como Garrincha, é porque em todos eles há o personalismo de Joaquim, que soube moldá-los ao seu estilo e tonalidade, dando lhes, aos personagens, uma dimensão épica e central para a interpretação da vida nacional em 
seus principais momentos. Tornava-se, com isso, a "coluna mestra do Kynema Novo Brazyleyro" (ROCHA, 28 out. 1978, p. 32). Essa simbiose entre as dimensões da representação dos personagens e a dimensão da representação do intelectual talvez fique mais evidente em um trecho selecionado:

"Bandeira, Gylberto, Gatos desencourados por capitães de areia nas favelas cariocas, Padre foge com Moça perseguidos pelo fanatismo católico subdesenvolvido das Mynas Geraes decadentes, Macunaíma o herói sem nenhum caráter do Modernysmaryandandrá, Inkofidentes da Heuztórya do Brazyl e casais de várias classes em Guerra Conjugal.

Qual a relação entre

Manuel Bandeira

Gylberto Freyre

Gatos

Pivetes

Padre

Moça

Macunaíma.

GARRINCHA é Makunayma Negro

Tyradentes (Joaquim seria Tomaz Antonio Gonzaga e Cristina Axé Marília de Dirceu).

Tyradentez é Makunayma Louro.

Joaquim Pedro foi preso algumas vezes, sob acusações de 'Karakter polytyk' [...]Se de Manuel;Gilberto a Couro de Gato/Padre;Inconfidentes/Guerra há um Pedro, há um Joaquim em Macunaíma, e um J. Pedro em Garrincha.

Andrade monta estas contradições: Padre um quarteto, Macunaíma uma Synfonya, Inconfidência operística épica, Guerra cômica dos sexos" (ROCHA, 28 out. 1978, p. 32 ).

Não há sombra de dúvida que Glauber aproxima Joaquim Pedro de Andrade da figura épica que se construiu em torno de José de Alencar. Não sem razão. Isolado e ainda crente de que seria capaz de reorganizar em termos programáticos o grupo de cinema-novistas de maior destaque, Glauber viu na estratégia de abordar um de seus integrantes, talvez o mais visível dos herdeiros da tradição literária modernista em nosso cinema, uma cartada de mestre: ao mesmo tempo em que ele propunha uma nova aliança com um dos seus mais fortes representantes de seu mais saudoso passado, ele também registrava a continuidade e ramificação no cinema, pela primeira vez na nossa história cultural, da reconhecida e consagrada tradição literária moderna. A quem quisesse ouvir, Glauber só vinha confirmar uma ideia sua: do mesmo modo que Alencar havia colocado a nação no rol de produtores da forma romanesca, o Cinema Novo conseguira alçar a nação entre os mais distintivos produtores de cinema moderno. 
Do mesmo modo que esse seu intento procurava definir e destacar a marca de inovação do grupo cinema-novista - um grupo quase de heróis míticos sob sua concepção-, não se deve esquecer que, em igual disposição, embora um tanto velada, sua tentativa considerava ainda a necessidade de evitar a abordagem de eventuais desajustes e mesmo alianças mais conservadoras que, porventura, pudessem ter eles se beneficiados dentro da dinâmica do funcionamento do campo cinematográfico em expansão no Brasil dos anos 1960 e 1970.

Em todos os sentidos, por esta e outras razões, que José de Alencar se tornava personagem modelar. Se não o patrono das nossas letras, já ganhava, por parte de Glauber, algum fôlego para se tornar o patrono do nosso cinema. Sendo ele um homem de um tempo que sequer o cinema existia, e vindo de quem veio, tal feito não é pouca coisa. Cheio de cousas e lousas, o feito revelava matéria digna para um bom conto de Machado. Embora Glauber fosse discordante de muitas ideias de Roberto Schwarz, uma talvez ele devesse concordar com o crítico: "de Iracema, alguma coisa veio até Macunaíma” (SCHWARZ, 200o, p. 38-39).

\section{REFERÊNCIAS BIBLIOGRÁFICAS}

ADORNO, Theodor. Sinais de pontuação. In: Notas de literatura I. Trad. Jorge M. B. de Almeida. São Paulo: Editora 34, 2003.

AGUIAR, Flávio. A tréplica de Flávio a Glauber. O Pasquim. Rio de Janeiro (RJ), 10-16 set. 1976, p. 19.

. Alencar e Machado, uma falsa polêmica. Movimento. São Paulo (SP), 20 set. 1976, p. 18.

. E geme o sino em lúgubres responsos Pobre Glauber! Pobre Glauber! (ou: 'Nem Lênin, nem Stalin, nem Marx, nem mesmo Machado de Assis'. E muito menos Glauber Rocha). Movimento. São Paulo (SP), 9 ago. 1976, p. 15.

BENTES, Ivana. Introdução. In: ROCHA, Glauber. Cartas ao mundo. São Paulo: Companhia das Letras, 1997.

CAMPOS, Haroldo de. Uma poética da radicalidade. In: ANDRADE, Oswald de. Paubrasil, Editora Globo, 2000.

GOMES, Paulo Emílio Salles."Debate sobre Revisão crítica do cinema brasileiro”. In: ROCHA, Glauber. Revisão crítica do cinema brasileiro. São Paulo: Cosac Naify, 2003. [Última Hora, São Paulo (SP), 9 nov. 1963, p. 6-9]

MICELI, Sergio. Intelectuais à brasileira. São Paulo: Companhia das Letras, 2001. 
ROCHA, Glauber. ‘O Guarany’ e ‘Dom Casmurro’ ou a competição entre Iracema e Capitu pelo título de Misse Brazyl. Jornal do Brasil. Rio de Janeiro (RJ), 6 set. 1976, p. 10. . Glauber Rocha de volta. Jornal do Brasil. Rio de Janeiro (RJ), 26 jun. 1976, p. 1. [Depoimento à Mary Ventura].

. Goal de Figueredo. Folha de S. Paulo. São Paulo (SP), 17 jun. 1978, p. 30.

. Kranyo. Folha de S. Paulo. São Paulo (SP), 10 jun. 1978, p. 32.

. Limite. Folha de S. Paulo. São Paulo (SP), 3 jun. 1978, p. 30.

. Makunayma - 2. Folha de S. Paulo. São Paulo (SP), 28 out. 1978, p. 40.

. Makunayma (1). Folha de S. Paulo. São Paulo (SP), 23 set. 1978, p. 32.

. Nem Lênin, Nem Mao, nem Stalin, nem mesmo Machado de Assis. Movimento. São Paulo (SP), 19 jul. 1976, p. 19. [Depoimento a Narciso Lobo].

. Querem me matar (ou, votem na Arena). O Pasquim. Rio de Janeiro (RJ), 13-19 ago. 1976, p. 14.

SCHWARZ, Roberto. Ao vencedor as batatas. São Paulo: Editora 34, 2000.

SENADOR veta Machado e afirma que Alencar deve ser patrono das Letras. Jornal do Brasil, Rio de Janeiro (RJ), 2 set. 1976.

VIANA, Luiz. Discurso. Diário do Congresso Nacional. Brasília (DF), Seção II, 2 set. 1976, p. 5336-5337. [Discurso do senador Luiz Viana, proferido em 1 set. 1976]. 